Egypt. J. of Appl. Sci., 35 (11) 2020

143-157

\title{
EFFECT OF BANANA (Musa Balbisiana) FRUITS AND ITS PEELS ON ACUTE HEPATOTOXICITY WITH DIABETIC RATS
}

Reham Zakaria ; Mohamed S. Abelbaky and Alaa O Abo-Raya

Nutrition and Food Science Dept., Faculty of Home Economics, Helwan University

Key Words: banana fruit- Peels- Diabetic rats- Glucose- Insulin activity- Liver and Kidney functions- Lipids profile.

\begin{abstract}
Nowadays, tend to use synthetic drugs to lower serum liver functions and glucose level in diabetic patients is gradually decreased because of their related side effects, as well as a progression of drug resistance. In this regard, tend to use of medicinal plants has been doubled. Therefore, the aim of the present study was to investigate the effect of Banana (Musa Balbisiana) fruits and its peels on acute hepatotoxicity with diabetes. Thirty six adult male rats were classified into 6 groups (6 rats each), Group (1), were fed on basal diet (control negative group). Rats $(n=30)$ were injected by single intraperitoneal freshly prepared Streptozotocin $(60 \mathrm{mg} / \mathrm{kg}$ b.wt.), these Animals were randomly enrolled into five groups as following: Group (2), diabetic rats were fed on basal diet (control positive group). Groups (3 and 4), diabetic rats were fed on basal diet supplemented with $5 \%$ and $10 \%$ dried banana fruit respectively. Group (5 and 6), diabetic rats were fed on basal diet supplemented with $5 \%$ and $10 \%$ dried peel of banana fruit, respectively. All rats except control negative will be subcutaneous injected by carbon tetrachloride $\left(\mathrm{Ccl}_{4}\right)$, twice at the end of experimental (4 weeks) feeding period to induce acute hepatotoxicity .

The results of the current study showed that basal diet supplemented with dried banana fruit or banana peels at the two studied level (5\% and 10 $\%)$ caused a significant decrease $(\mathrm{P}<0.05)$ in the elevate level of serum glucose, urea, uric acid, creatinine, triglycerides, total cholesterol, low density lipoprotein, very low density lipoprotein, aspartate aminotransferase, alanine aminotransferase and alkaline phosphatase levels, and significantly increased $(\mathrm{P}<0.05)$ the concentrations of high density lipoprotein and insulin activity as compared to the control diabetic rats. No statistical changes among the treated groups for all parameters were observed. The present study demonstrates that banana fruit and its peel has hepatoprotective, hypoglycemic effects against diabetic hepatotoxic rats .
\end{abstract}

\section{INTRODUCTION}

Diabetes mellitus is an endocrine dysfunction resulting from insulin deficiency or incapability of peripheral tissues to respond to insulin (Singh et al., 2008). The cumulative effects of metabolic disorders of diabetes lead to cell damage, circulatory changes and eventually to 
cardiovascular disorders including increased plasma lipoproteins, atherosclerosis, hypertension and cardiomyophathy. Other clinical consequences of diabetes include nephropathy, neuropathy, retinopathy and liver dysfunction (Vidro et at., 1999). Chronic hyperglycemia causes damage to the eyes, kidneys, nerves, heart and blood vessels (Susman and Helseth, 1997).

The world prevalence of diabetes among adults (aged 20-79 years) was $6.4 \%$, affecting 285 million adults, in 2010 , and will be increased to $7.7 \%$, affecting 439 million adults by 2030 . It has been estimated that by the year 2030, there will be 8.6 million adults with diabetes in Egypt, making it the country with the tenth largest population of diabetics in the world (Shaw et al., 2010). Reasons for this rise includes an increase in sedentary lifestyle, the consumption of energy-rich diet, obesity, and a higher life span, etc. (Yajmk, 2001).

Diabetes mellitus is probably the fastest growing metabolic disease in the world and as knowledge of the heterogeneous nature of the disease increases so we need for more challenging and appropriate therapies. Traditional plant remedies have been used for centuries in the treatment of diabetes (Kesari et al., 2005). The use of traditional medicine and medicinal plants in most developing countries, as a normative basis for the maintenance of good health, has been widely observed (Tiwari and Madhusudanarao, 2002).

Among the numerous fruit yielding plants, that provide medicinal properties banana is a major fruit. It has been reported that there are 30 different varieties of banana (Family: Musaceae) available in the world (Lehmann et al., 2002). Various parts of the plant can be used for the treatment of various diseases including diabetic, diarrhea, scabies and inflammations as all parts of the plant exhibit different pharmaceutical properties (Rai et al., 2009). To get low-fat, low-sodium, and cholesterol-free diet, the banana is suitable for consumption making it particularly recommendable for people with cardiovascular and kidney problems, arthritis, gout, or gastrointestinal ulcers (Sumathy et al., 2011).

Much study has been done regarding the various medicinal properties of different Musa sp. It was reported that M. sapientum L. (Family: Musaceae) fruits increases insulin secretion by pancreatic $\beta$ cells and enhances peripheral glucose utilization, in STZ induced rat (Ojewole and Adewunmi, 2003). Therefore, the aim of the present study was conducted to evaluate the effect of banana (Musa Balbisiana) fruits and its peels on $\mathrm{Ccl}_{4}$ - induced acute hepatotoxicity in diabetic rats. 
Materials:-

\section{MATERIALS AND METHODS}

Plant: Banana (Musa Balbisiana) fruits was obtained from agricultural research center. Chemicals: Streptozotocin (STZ) and $\mathrm{Ccl}_{4}$ were obtained from local distributer of (Sigma Chemical Co) Cairo, Egypt. Casein, vitamins, minerals, cellulose and L-cysteine were purchased from El-Gomhorya Company for Chemical and Pharmaceutical, Cairo, Egypt. Kits for blood analysis were purchased from Alkan Company for Biodiagnostic Reagents, Dokki, Giza, Egypt. Rats: adult male albino rats (Sprague- Dawley strain) ( $\mathrm{n}=36$ rats) weighting approximately $(200 \pm 5 \mathrm{~g})$ were purchased from Helwan Experimental Animals Farm.

\section{Methods:-}

A. Preparation of materials: Banana fruits with peels was washed, brushed under distilled water, air dried and hand peeled. Banana Fruits and isolated peels from the flesh were dried using solar energy at (National Research Center, Dokki, Giza), then were grinded by an electric Grinder.

\section{B. Experimental animals:}

Thirty six adult male rats were fed on basal diet prepared according to (Reeves et al., 1993) for one week before the experiment for adaptation. The animals housed individually in stainless steel cages under controlled condition, at the Animal House of Faculty of Home Economic, Helwan University. Diabetes was induced to rats by single intraperitoneal injection of freshly prepared Streptozotocin $(60 \mathrm{mg} / \mathrm{kg}$ b.wt.). Three days after STZ administration, serum glucose level of each rat was measured. Rats with fast serum glucose $(\geq 200 \mathrm{mg} / \mathrm{dl})$ were considered diabetic (Sarkar et al., 1996). Animals were randomly enrolled into six groups (6 rats each) as following:

Group (1), rats were fed on basal diet (control negative group). Group (2), diabetic rats were fed on basal diet (control positive group). Groups (3 and 4), diabetic rats were fed on basal diet supplemented with $5 \%$ and $10 \%$ dried banana fruit respectively. Group (5 and 6), diabetic rats were fed on basal diet supplemented with $5 \%$ and $10 \%$ dried peel of banana fruit, respectively.

All rats except control negative will be subcutaneous injected by carbon tetrachloride $\mathrm{Ccl}_{4}$ that diluted by paraffin oil (1:1) \{ in a dose of 2 $\mathrm{ml} / \mathrm{kg}$ of BW. of rat $\}$, twice at the end of experimental feeding period to induce acute hepatotoxicity according to the method described by (Wilfried, et al.,1994).

Each rat was weighted at the end of experiment and feed intake (FI) was also recorded daily. At the end of experimental period (4 weeks), rats were sacrificed after overnight fasting and blood of each rat was taken from the abdominal aorta under anesthesia by diethyl ether. The 
serum was separated by leaving the blood samples 15 minutes at room temperature then centrifuged at $3000 \mathrm{rpm}$ for 20 minutes, and then kept in plastic vials at $-20^{\circ} \mathrm{C}$ until biochemical analysis.

The biological effect of different levels of banana fruits and its peel were assessed by the determination of body weight gain percent $(\mathrm{BWG} \%)$ and feed efficiency ratio (FER) according to the method of Chapman et al., (1959) .

\section{Biochemical analysis of serum:}

Insulin activity was estimated using enzyme linked immunosorbent assay ELISA method as described by Clark and Hales, (1994). Glucose level was determined according to Asatoor and King, (1954). Calorimetric determination of total cholesterol and triglycerides were carried out according to the method of Richmond, (1973) and Fossati and Praneipe, (1982) respectively. Determination of HDL-c level was carried out according to the method of Richmond, (1973). VLDL-c and LDL-c were calculated according to the equation of Friedewald $\boldsymbol{e t}$ al., (1972). Serum aspartate aminotransferase (AST) and alanine aminotransferase (ALT) were determined according to method of Reitman and Frankel, (1957). Serum alkaline phosphatase (ALP) is estimated by method of Belfield and Goldberg, (1971). Serum creatinine, urea and uric acid level was determined by the method Tietz, (1999), Wills and Savory, (1981) and Patton and Crouch, (1977) respectively.

\section{Statistical analysis:}

The results were expressed as mean \pm SE. The statistical analysis was carried out by using SPSS, PC statistical software (Version 19.0 SPSS Inc., Chieago, USA) using the Duncan' test multiple range posthoc test. Data was analyzed by one way analysis of variance (ANOVA). The values were considered significantly different at $(\mathrm{P}<0.05)$ (Zar, 1984)

\section{RESULTS AND DISCUSSION}

Nowadays there is an increased demand for using plants in therapy "back to nature" instead of using synthetic drugs which may have adverse effects. Traditional medicinal plants are often cheaper, locally available, and easily consumable as raw or as simple medicinal preparations. These plants often mediate beneficial responses due to their active chemical constituents (Amin and Nagy, 2009). Therefore, the aim of the present study is to investigate the effect of banana fruit and its peels at two levels (5\% and 10\%) on glucose, lipid profile, kidney and liver function of diabetic rats.

As shown in table (1), the initial body weight for all rats ranged between $(200.00 \pm 1.32$ to $203.50 \pm 1.05 \mathrm{~g})$, with no significant differences 
between all rats. Diabetic rats had lowered FBW, BWG\% and FER as compared to the negative control group, while feed intake was higher as compared to other groups. These results are in agreement with (Veermanic et al., 2008) who mentioned that, in STZ-induced diabetic rats, degradation and loss of structural proteins were the main reasons of body weight reduction.

Table (1): Effect of banana fruit and its peels on body weight of diabetic rats with induced hepatotoxicity.

\begin{tabular}{|c|c|c|c|c|c|}
\hline $\begin{array}{l}\text { Parameters } \\
\text { Groups }\end{array}$ & IBW (g) & FBW (g) & BWG\% & $\begin{array}{c}\text { FI } \\
\text { (g/day/rat) }\end{array}$ & FER \\
\hline Control (-ve) & $200.00 \pm 1.32^{\mathrm{a}}$ & $250.00 \pm 2.02^{a}$ & $25.00 \pm 0.86^{a}$ & 16.00 & $0.104 \pm 0.05^{a}$ \\
\hline Control (+ve) & $203.50 \pm 1.05^{a}$ & $181.20 \pm 2.43^{\mathrm{c}}$ & $-10.95 \pm 1.84^{c}$ & 19 & $-0.039 \pm 0.08^{c}$ \\
\hline Banana fruit (5\%) & $201.20 \pm 1.06^{\mathrm{a}}$ & $230.83 \pm 1.64^{b}$ & $14.72 \pm 3.11^{b}$ & 13.50 & $0.073 \pm 0.19^{b}$ \\
\hline Banana fruit $(10 \%)$ & $202.75 \pm 1.49^{a}$ & $231.22 \pm 1.25^{b}$ & $14.04 \pm 2.41^{b}$ & 14.00 & $0.067 \pm 0.18^{b}$ \\
\hline Banana peels $(5 \%)$ & $201.50 \pm 1.19^{a}$ & $234.75 \pm 1.30^{b}$ & $16.50 \pm 2.58^{b}$ & 13.00 & $0.085 \pm 0.20^{b}$ \\
\hline Banana peels $(10 \%)$ & $202.00 \pm 1.24^{\mathrm{a}}$ & $231.00 \pm 1.88^{b}$ & $13.35 \pm 3.80^{b}$ & 13.85 & $0.069 \pm 0.28^{b}$ \\
\hline
\end{tabular}

*Values were expressed as Means \pm SE.

* Values at the same column with different letters are significant at $\mathbf{P}<0.05$.

It was observed that, the FBW, BWG\% and FER for all treated rats at the tow studied levels were significantly increased $(\mathrm{P}<0.05)$ compared to the corresponding values of control positive group. While the daily feed intake was lowered for all treated groups as compared to diabetic positive group. Moreover, there are no significant changes among the treated groups fed either banana fruit or its peel for FBW, BWG\% and FER at the tested levels. Dhanabal et al., (2005) proved that banana peels supplemented diet caused varying percentage weight gains in all groups, which were not statistically significant when compared to the control.

Effect of banana fruit and its peel at two different levels on serum glucose level and insulin activity in diabetic rats were shown in table (2). Diabetic group (Control $+v e)$ exhibit significant increase $(\mathrm{P}<0.05)$ in the mean values of serum glucose level as compared to the control negative group, while illustrated a significant decrease $(\mathrm{P}<0.05)$ of insulin activity in diabetic group as compared to the mean values of control negative group. Hull et al., (2004) reported that, diabetes type I affects pancreatic cells, which are responsible for producing insulin, by inhibiting immune response. However, in type II diabetes, cells become resistant to the use of insulin. Although pathogenesis of diabetes type I and type II is different, defects in insulin secretion and/or action, carbohydrates, lipids and proteins metabolism impairment are some of the main diabetic complications. 
Feeding diabetic rats on diet supplemented with banana fruit and its peel at two levels $(5 \%$ and $10 \%)$ caused a significant decrease $(\mathrm{P}<0.05)$ in the elevated serum glucose level as compared to the +ve group. The percent of glucose reduction as a result of supplementation with banana fruit and its peel are (44.18, 45.33, 43.43 and 44.69\%) respectively, as compared to the value of glucose level in +ve group. It was clear that, there were no significant differences in glucose level among the treated groups. On the other hand, the level of insulin activity was significantly $(\mathrm{P}<0.05)$ increased at the treated groups as compared to control diabetic group. Moreover, there were no significant differences in insulin activity level among the treated groups with banana fruit and its peel at two levels (5\% and $10 \%)$.

Table (2): Effect of banana fruit and its peels on fasting serum glucose level and insulin activity of diabetic rats with induced hepatotoxicity.

\begin{tabular}{|c|c|c|c|}
\hline $\mathrm{Cr}_{\text {Groups }}$ Parameters & $\begin{array}{l}\text { Glucose } \\
\text { (mg/dl ) }\end{array}$ & $\begin{array}{l}\text { \%of glucose } \\
\text { reduction }\end{array}$ & $\begin{array}{c}\text { Insulin } \\
(\mathrm{mIU} / \mathrm{ml})\end{array}$ \\
\hline Control (-ve) & $93.00 \pm 1.41^{\mathrm{c}}$ & Zero & $17.11 \pm 0.34^{\text {a }}$ \\
\hline Control (+ve) & $275.03 \pm 2.25^{\mathrm{a}}$ & Zero & $6.89 \pm 0.57^{\mathrm{c}}$ \\
\hline Banana fruit $(5 \%)$ & $153.50 \pm 1.92^{b}$ & 44.18 & $11.00 \pm 0.62^{b}$ \\
\hline Banana fruit $(10 \%)$ & $150.34 \pm 1.00^{b}$ & 45.33 & $12.10 \pm 0.55^{b}$ \\
\hline Banana peels $(5 \%)$ & $155.57 \pm 1.07^{b}$ & 43.43 & $10.21 \pm 0.41^{b}$ \\
\hline Banana peels $(10 \%)$ & $152.11 \pm 1.32^{b}$ & 44.69 & $10.17 \pm 0.23^{b}$ \\
\hline
\end{tabular}

*Values were expressed as Means $\pm \mathrm{SE}$.

* Values at the same column with different letters are significant at $\mathbf{P}<0.05$.

Banana peel is a rich source of starch (3\%), crude protein (6-9\%), crude fat (3.8-11\%) and total dietary fibre (43.2- 49.7\%) (Mohapatra et al., 2010). dietary fibers lowered postprandial serum glucose levels at least by three mechanisms. First, dietary fibers increase the viscosity of small intestine juice and hinder diffusion of glucose, second, they bind glucose and decrease the concentration of available glucose in the small intestine and, third, they retard $\alpha$-amylase action through capsuling starch and the enzyme and might directly inhibit the enzyme, all of these decreased the absorption rate of glucose and the concentration of postprandial serum glucose (Ou et al., 2001). These dietary fiber in food have been shown to be useful in reducing blood glucose levels in diabetes, in reducing blood cholesterol levels, for treatment of cardiovascular disease and also in preventing bowel cancer (Mann and Truswell, 2002).

Bioactive compounds such as alkaloids, anthocyanins, flavonoids, glycosides, phlobatannins, tannins, and terpenoids have been reported in banana peels, and these compounds have been shown to exert various 
biological and pharmacological effects (antibacterial, antihypertensive, antidiabetic, and anti-inflammatory activities) (Pereira and Maraschin, 2015).

The lipid profile of +ve group was significantly increased, while HDL-C was significantly decreased as compared to -ve as seen in table (3). The level of TC was significantly lowered for all treated groups as compared to +ve group. it was cleared that the higher level of banana fruit or banana peels , the lower level of TC. Regarding to serum TG and VLDL-c, STZ injection caused a significant increase in the level of TG and VLDL-c as compared to -ve group. The diabetic rats that treated with the banana fruit or banana peels at the tested levels had significant decrease of the value of TG and VLDL-c as compared to positive control group. There were no significant changes between banana fruit $(5 \%)$ and banana fruit $(10 \%)$ as well as between banana peels at the two tested levels.

The level of LDL-c was significantly decreased due to supplementation with either banana fruit or peels of banana at the tested levels as compared to positive control group. there were no significant changes between the two tested level. The mean level of HDL-c was significantly increased for all treated groups as compared to positive group. The highest hypolipidemic effect was observed at the groups fed either banana fruit $(10 \%)$ or banana peels $(10 \%)$.

Table (3): Effect of banana fruit and its peels on lipid profile of diabetic rats with induced hepatotoxicity

\begin{tabular}{|c|c|c|c|c|c|}
\hline \multirow{2}{*}{$\begin{array}{ll}\text { Groups } & \text { Parameters } \\
\end{array}$} & TC & TG & HDL-C & VLDL-C & LDL-C \\
\hline & \multicolumn{5}{|c|}{ (mg/dl ) } \\
\hline Control (-ve) & $116.87 \pm 1.14^{\mathrm{e}}$ & $97.24 \pm 1.45^{d}$ & $64.58 \pm 2.08^{a}$ & $19.44 \pm 0.44^{d}$ & $32.82 \pm 1.99^{d}$ \\
\hline Control (+ve) & $170.40 \pm 1.35^{a}$ & $220.20 \pm 2.71^{a}$ & $32.17 \pm 1.07^{d}$ & $44.04 \pm 0.36^{a}$ & $94.19 \pm 2.11^{a}$ \\
\hline Banana fruit (5\%) & $139.07 \pm 0.95^{\mathrm{c}}$ & $149.31 \pm 1.83^{c}$ & $44.16 \pm 2.18^{b c}$ & $29.86 \pm 0.36^{c}$ & $65.05 \pm 2.45^{b}$ \\
\hline Banana fruit $(10 \%)$ & $130.16 \pm 1.92^{d}$ & $141.48 \pm 1.25^{c}$ & $46.00 \pm 1.03^{b}$ & $28.29 \pm 0.25^{c}$ & $55.87 \pm 2.88^{c}$ \\
\hline Banana peels $(5 \%)$ & $147.56 \pm 1.57^{b}$ & $170.50 \pm 2.06^{b}$ & $40.34 \pm 1.11^{c}$ & $34.10 \pm 0.67^{b}$ & $73.12 \pm 2.29^{b}$ \\
\hline Banana peels $(10 \%)$ & $133.03 \pm 1.44^{d}$ & $162.50 \pm 1.25^{b}$ & $45.33 \pm 1.30^{b}$ & $32.50 \pm 0.21^{b}$ & $55.20 \pm 1.41^{\mathrm{c}}$ \\
\hline
\end{tabular}

*Values were expressed as Means $\pm \mathrm{SE}$.

* Values at the same column with different letters are significant at $\mathbf{P}<0.05$

In the healthy rats, lipoprotein lipase is activated by insulin, which hydrolyzes triglycerides; hypertriglyceridemia happens due to insulin deficiency after STZ injection in diabetic rats (Taskinen, 1987). Increased level of lipids in diabetes may cause cardiovascular complications (Heather and Clarke, 2011).

Animal studies have shown that banana has the potential to lower cholesterol. It was suggested that the dietary fiber component in banana pulp was responsible for its cholesterol-lowering effect. The amount of 
dietary fiber in banana is relatively constant during banana ripening (Sampath et al., 2012).

Plants rich in polyphenolic compounds have been reported to play a key role in reducing the progression of chronic diseases such as cardiovascular diseases, cancer, tumorigenesis, diabetes, and chronic inflammatory disorders (Kumari et al., 2016). Recent data also reported its effects in the treatment of diabetes and hyperlipidemia (Kalita et al., 2016). Intake of chlorogenic acid, quercetin and apigenin, present in Musa balbisiana fruit powder, have been associated with a decreased risk of cardiovascular disease and type 2 diabetes (Bhandarkar et al., 2019).

The peels of banana, constitute up to $35 \%$ of the ripe fruit, and are regarded as household and industrial food waste, being discarded in large quantities (Emaga et al., 2008). Musa acuminata fruit peels are used in the northern part of Nigeria for the treatment of hypertension and other cardiovascular related diseases (Edenta et al., 20141). Moreover, Kumari et al., (2020) suggests that supplementation of dried Musa balbisiana fruit powder can be useful for the prevention of cardiac hypertrophy via the inhibition of inflammation and oxidative stress.

Table (4) illustrates the effects of banana fruit and its peel at two different levels in kidney functions on diabetic hepatotoxic rats. Injection with STZ $(60 \mathrm{mg} / \mathrm{kg}$ b.wt.) significantly increase $(\mathrm{P}<0.05)$ the level of urea, uric acid and creatinine as compared to the control normal group (control -ve). Feeding diabetic rats on diet supplemented with banana fruit and its peel at two levels (5\% and 10\%) caused a significant decrease $(\mathrm{P}<0.05)$ in the mean values of uric acid, creatinine and urea as compared to positive control group. Moreover, there were no significant changes in kidney functions among the treated groups with either banana fruit and its peel at the two tested levels.

Table (4): Effect of banana fruit and its peels on kidney functions of diabetic rats with induced hepatotoxicity

\begin{tabular}{|c|c|c|c|}
\hline \multirow{2}{*}{$\begin{array}{ll}\text { Groups } & \text { Parameters } \\
\end{array}$} & Urea & Uric acid & Creatinine \\
\hline & \multicolumn{3}{|c|}{$(\mathrm{mg} / \mathrm{dl})$} \\
\hline Control (-ve) & $40.13 \pm 1.88^{c}$ & $1.00 \pm 0.07^{\mathrm{c}}$ & $0.61 \pm 0.02^{c}$ \\
\hline Control (+ve) & $80.00 \pm 2.98^{a}$ & $2.97 \pm 0.20^{a}$ & $2.00 \pm 0.01^{a}$ \\
\hline Celery plant $(5 \%)$ & $66.40 \pm 0.95^{b}$ & $1.61 \pm 0.11^{b}$ & $1.13 \pm 0.10^{b}$ \\
\hline Celery plant $(10 \%)$ & $64.12 \pm 0.74^{b}$ & $1.54 \pm 0.13^{b}$ & $1.09 \pm 0.17^{b}$ \\
\hline $\begin{array}{l}\text { Celery seeds }(5 \%) \\
\text { Celery seeds }(10 \%)\end{array}$ & $\begin{array}{l}67.70 \pm 0.70^{b} \\
66.52 \pm 0.50^{b}\end{array}$ & $\begin{array}{l}1.65 \pm 0.08^{b} \\
1.72 \pm 0.05^{b}\end{array}$ & $\begin{array}{l}1.25 \pm 0.14^{b} \\
1.19 \pm 0.24^{b}\end{array}$ \\
\hline
\end{tabular}

*Values were expressed as Means \pm SE .

* Values at the same column with different letters are significant at $\mathbf{P}<0.05$ 
Data in table (5) revealed the effect of banana fruit and its peel on liver function enzymes of diabetic rats with induced hepatotoxicity. The activities of serum ALT, AST and ALP were significantly increased $(\mathrm{P}<0.05)$ in the diabetic hepatotoxic group as compared with the corresponding value of normal control group.

Table (5): Effect of banana fruit and its peels on liver functions on diabetic rats with induced hepatotoxicity

\begin{tabular}{|c|c|c|c|}
\hline \multirow{2}{*}{$\begin{array}{l}\text { Parameters } \\
\text { Groups }\end{array}$} & ALT & AST & ALP \\
\hline & \multicolumn{3}{|c|}{$\mu / \mathbf{L}$} \\
\hline Control-ve & $34.16 \pm 0.83^{c}$ & $90.87 \pm 1.22^{\mathrm{e}}$ & $35.90 \pm 1.56^{\mathrm{c}}$ \\
\hline Control +ve & $74.23 \pm 2.55^{a}$ & $162.69 \pm 1.35^{a}$ & $60.76 \pm 2.46^{\mathrm{a}}$ \\
\hline Celery plant $5 \%$ & $55.10 \pm 1.32$ & $149.74 \pm 1.39^{b}$ & $49.25 \pm 1.30^{b}$ \\
\hline Celery plant $10 \%$ & $51.34 \pm 1.58^{b}$ & $130.12 \pm 1.49^{c}$ & $46.85 \pm 1.80^{b}$ \\
\hline $\begin{array}{l}\text { Celery seeds } 5 \% \\
\text { Celery seeds } \mathbf{1 0 \%}\end{array}$ & $\begin{array}{l}54.22 \pm 1.20^{b} \\
53.17 \pm 1.13^{b}\end{array}$ & $\begin{array}{l}132.34 \pm 2.52^{c} \\
124.10 \pm 1.10^{d}\end{array}$ & $\begin{array}{l}52.02 \pm 1.58^{b} \\
50.48 \pm 1.20^{b}\end{array}$ \\
\hline
\end{tabular}

*Values were expressed as Means \pm SE .

* Values at the same column with different letters are significant at $\mathbf{P}<0.05$

The elevation of serum AST and ALT level might be due to the release of these enzymes from the cytoplasm, into the blood circulation rapidly after rupture of the plasma membrane and cellular damage. ALP is an ecto-enzyme of hepatocyte plasma membrane; an increase in serum ALP reflects the pathological alteration in biliary flow and damage to the liver cell membrane (Dunsford et al., 1989). High concentrations of serum transaminases are considered to be an index of hepatic injury where elevation of ALT is regarded as a more sensitive indicator and is usually accompanied by a rise in AST (Ha et al., 2001).

Feeding diabetic hepatotoxic rats on dried banana fruit and its dried peel at two level (5\% and 10\%) caused significant decrease $(\mathrm{P}<0.05)$ in the mean value of ALT, AST and ALP levels as compared to the control positive group. There were no significant changes in the level of serum ALT and ALP among the groups fed either banana fruit or its peel at the level of 5 or $10 \%$, while, rats feeding on peel banana fruit at $10 \%$ had the lowest reduction in the level of serum AST as compared to other groups.

Mosa and Kkalil (2015) found that the consumption of fresh and dried banana peels may modify the risk of acute liver failure patients. Banana should be considered to be a good source of natural antioxidant for foods and functional food source against cancer and heart disease (Someya et al., 2002). Therefore, attention in recent times has been focused on the isolation, characterization and utilization of natural antioxidants, especially growing interest in polyphenols as potential disease preventing agents. Bananas are one of the most popular fruits in the world and it well be known that fruits contain various antioxidants 
compounds such as gallocatechin and dopamine (Mokbel and Hashinaga, 2004). Moreover, it was established that dietary phenolic compounds such as chlorogenic acid, quercetin and apigenin have been associated with reducing the risk of both chronic and acute diseases (Bhandarkar et al., 2019). These therapeutic responses to polyphenols have been attributed to their antioxidant and anti-inflammatory properties (Wang et al., 2018 and Agunloye et al., 2019).

Banana peel represents about $40 \%$ of total weight of the fresh fruit (Anhwange et al., 2008). The total amount of phenolic compounds in banana peel has been ranged from 0.90 to $3.0 \mathrm{~g} / 100 \mathrm{~g}$ dry weight and gallocatechin is identified at a concentration of $160 \mathrm{mg} / 100 \mathrm{~g}$ dry weight; Someya et al. (2002). Other phytochemicals such as anthocyanin, delphinidin, cyaniding; Seymour, and catecholamines have been identified (Kanazawa and Sakakibara, 2000) in ripe banana pulp and peel. Some studies demonstrated that banana peel generally includes higher phenolic compounds than those of banana pulps; Sulaiman et al., (2011). According to the study by Someya et al. (2002) total phenolics are more abundant in peel $(907 \mathrm{mg} / 100 \mathrm{~g}$ dry wt.) than in pulp (232 $\mathrm{mg} / 100 \mathrm{~g}$ dry wt.) in Musa cavendish.

Abd El-baky and Ahmed, (2011) showed that the extract of some fruits and vegetables peels (apple, banana, red beet and potato) especially methanol extract has a significant protective effect against acute hepatotoxicity induced by $\mathrm{CCl} 4$ in rats, which may be due to its free radical scavenging effect and its ability to increase antioxidant activity.

Conclusion: Supplementation with banana fruit and banana peels at (5 and $10 \%$ ) significantly lowered the elevated blood glucose and increased the insulin in diabetic rats and also improving liver and kidney functions. These results may be due to components of banana fruit and banana peels such as phenolic compounds, vitamins, minerals and fibers that possess antioxidant, hepatoprotective, antilipidemic and antidiabetic activities. Therefore, banana fruit and banana peels may be suitable for treating diabetic patients with hyper liver enzymes.

\section{REFERENCES}

Abd El-baky, M. and F. Ahmed (2011): Effect of some fruits and vegetables peels extract on $\mathrm{CCl} 4$ induced hepatic injury in rats. Med. J. Cairo Univ. 79 (1):49-57.

Agunloye, O. ; G. Oboh ; A. Ademiluyi and et al., (2019): Cardioprotective and antioxidant properties of caffeic acid and chlorogenic acid: mechanistic role of angiotensin converting enzyme, cholinesterase and arginase activities in cyclosporine induced hypertensive rats," Biomedicine \& Pharmacotherapy, 109:450-458. 
Amin, K.A. and M.A. Nagy (2009): Effect of Carnitine and herbal mixture extract on obesity induced by high fat diet in rats. Diabetology \& Metabolic Syndrome, 1:17.

Anhwange, B.A.; T.J. Ugye and T.D. Nyiaatagher (2008): Chemical composition of Musa sapientum (banana) peels. Electron. J. Environ. Agric. Food Chem., 8 (6):437-442.

A.O.A.C. (2000): Official Methods of Analysis. $17^{\text {th }}$ Edition of AOAC International Published by AOAC International Sut Gaithersburg, Maryland.

Asatoor, A.M. and E.J. King (1954): Simplified calorimetric blood sugar method . Biochem.J.56:XIIV.

Belfield, A. and L. Goldberg (1971): D.M-Revised assay for serum phenyl phosphatase activity using 4- amino-antipyrine-enzyme., 12:561-573.

Bhandarkar, N.; L. Brown and S. Panchal (2019): Chlorogenic acid attenuates high-carbohydrate, high-fat diet-induced cardiovascular, liver, and metabolic changes in rats. Nutrition Research, 62:78-88.

Chapman, D.G.; R. Castilla and J.A. Campbell (1959) : Evaluation of protein in food. LA. Method for the determination of protein efficiency ratio. Can. J. Biochem. Physiol., 37:679 - 686.

Clark, P.M.S. and C.N. Hales (1994): How to measure plasma insulin, Diabet. Metab. Rev., 10: 79-90.

Edenta, C.; D.B. James ; O.A. Owolabi and S.I. Okoduwa (2014): Hypolipidemic effects of aqueous extract of three Cultivars of Musa sapientumfruit peel on poloxamer-407 induced hyperlipidemicwistar rats. Int. J. Pharm. Sci. Res., 5:1046-1051.

Emaga, T.H. ; S.N. Ronkart ; C. Robert ; B. Wathelet and M. Paquot (2008): Characterisation of pectins extracted from banana peels (Musa AAA) under different conditions using an experimental design. Food Chem., 108: 463-471.

Dhanabal, S.P.; M.R. Sureshkumar and B. Suresh (2005): Hypoglycemic effect of ethanolic extract of Musa sapientum on alloxan induced diabetes mellitus in rats and its relation with antioxidant potential. J. Herb Pharmacother., 5:7-19.

Dunsford, H.A. ; C. karnasuta ; J.M. Hunt and S. Sell (1989): Different lineages of chemically-induced hepatocellular carcinoma in rats defined by monoclo nal antibodies. Cancer Res., 49: 4894-4900.

Fossati, P. and L. Praneipe (1982): Triglycerides determination after enzymatic hydrolysis. Clin. Chem., 28:2077.

Friedewald, W.T.; K.T. Levy and D.S. Fredrickson (1972): Estimation of the concentration of low density lipoprotein 
cholesterol in plasma without use of the preparative ultracentrifuge. Clin. Chem., 226: 499-504.

Ha, W.S.; C.K. Kim ; S.H. Song and C.B. Kang (2001): Study on mechanism of multistep hepatotumorigenesis in rat: development of hepatotumorigenesis. J Vet Sci., 2(1):53-8.

Heather, L.C. and K. Clarke (2011): Metabolism, hypoxia and the diabetic heart. J Mol Cell Cardiol, 50(4):598-605.

Hull, R.L.; G.T. Westermark; P. Westermark and S.E. Kahn (2004): Islet amyloid: a critical entity in the pathogenesis of type 2 diabetes. J Clin Endocrinol Metab., 89(8):3629-3643.

Kalita, H.; D. Boruah; M. Deori and et al., (2016): Antidiabetic and antilipidemic effect of Musa balbisiana root extract: a potent agent for glucose homeostasis in streptozotocininduced diabetic rat," Frontiers in Pharmacology, 7:102.

Kanazawa, K. and H. Sakakibara (2000): High content of dopamine, a strong antioxidant, in Cavendish banana. J. Agric. Food Chem., 48 (3):844-848.

Kesari, A.N.; R.K. Gupta and G. Watal (2005): Hypoglycemic effects of Murraya koenigiion normal and alloxan diabetic rabbits. J. Ethnopharmacol., 97: 247-25.

Kumari, S.; M. Deori ; R. Elancheran ; J. Kotoky and R. Devi (2016): In vitro and in vivo antioxidant, antihyperlipidemic properties and chemical characterization of Centella asiatica (L.) extract. Frontiers in Pharmacology, 7: 400.

Kumari, S.; P.Katare; R. Elancheran and et al., (2020): Musa balbisiana fruit rich in polyphenols attenuates isoproterenolinduced cardiac hypertrophy in rats via inhibition of inflammation and oxidative stress. Oxidative Medicine and Cellular Longevity, Pp:1- 14.

Mokbel, M.S. and F. Hashinaga (2004): Effect of heat, calcium chloride and modified atmosphere on the shelf life of banana fruits. Food Preserv. Sci.,30:179-184.

Mohapatra, D.; M.Sabyasachi and S. Namrata (2010): Banana and it by-product utilization: an overview. Journal of Scientific and Industrial Research, 69:323-329.

Mosa, Z. and A.Kkalil (2015): The effect of banana peels supplemented diet on acute liver failure rats. Annals of Agricultural Science, 60(2): 373-379

Ojewole, J. A. and C. O. Adewunmi (2003). Hypoglycemic effect of methanolic extract of Musa paradisiaca (Musaceae) green fruits in normal and diabetic mice. Methods Find. Exp. Clin. Pharmacol. 25: 453-456. 
Ou, S. ; K.C. Kwok ; Y. Li and L. Fu (2001): In vitro study of possible role of dietary fiber in lowering postprandial serum glucose. J. Agric. Food Chem., 49 (2):1026-1029.

Patton, C.J. and S.R. Crouch (1977): Calorimetric determination of blood urea. Analyt. Chem., 49: 464-469.

Pereira, A. and M. Maraschin (2015): Banana (Musa spp.) from peel to pulp: Ethnopharmacology, source of bioactive compounds and its relevance for human health. J. Ethnopharmacol., 160:149-163.

Reeves, R.G.; F.H. Nielsen and G.C. Fahey (1993): AIN-93 Purified Diets for Laboratory Rodents .J. Nutr., 123(1):1939-1951.

Reitman, S. and S.A. Frankel (1957): Colorimetric method for determination of serum glutamic oxaloacetic and glutamic pyruvic transaminases. Am J Clin Path., 28:56-63.

Richmond, N. (1973): Preparation properties of a cholesterol oxidase from nacardia SP. enzymatic assay of total cholesterol in serum. Clin Chem., 19: 1350-1356.

Sampath, K.P.; D.S. Debjit Bhowmik and M. Umadevi (2012): Traditional and medicinal uses of banana. J. Pharmacognosy Phytochem. 1 (3).

Sarkar, S.; M.Pranava and R.A. Marita (1996): Demonstration of the hyperglycemic action of Momordica charantia in a validated animal model of diabetes. Pharmacol. Res., 33: 1-4.

Shaw, J.E.; R.A. Sicree and P.Z. Zimmet (2010): Global estimates of the prevalence of diabetes for 2010 and 2030. Diabetes Research and Clinical Practice., 87(1): 4-14.

Singh, S.K.; P.K. Rai ; D. Jaiswal and G. Watal (2008) : Evidencebased critical evaluation of glycemic potential of Cynodon dactylon. Evid. Based Complement Alternat. Med 5 (4): 415-420.

Someya, S.; Y. Yoshiki and K. Okubo (2002): Antioxidant compounds from bananas (Musa Cavendish). Food Chem., 79:351-354.

Sulaiman, S.F.; N.A. Yusoff ; I.M. Eldeen ; E.M. Seow ; A.A. Sajak, and K.L. Ooi (2011): Correlation between total phenolic and mineral contents with antioxidant activity of eight Malaysian bananas (Musa sp.). J. Food Compos. Anal., 24:1-10.

Sumathy, V.; S. Jothy Lachumy ; Z. Zakaria and S. Sasidharan (2011). In vitro bioactivity and phytochemical screening of Musa acuminata flower. Pharmacologyonline., 2:118-12

Susman, J. and L. Helseth (1997): Reducing the complications of type II diabetes: a patient centered approach. Am Fam Physician., 56:471-80.

Taskinen M.R. (1987): Lipoprotein lipase in diabetes. Diabetes Metab Rev., 3(2):551-570. 
Tietz, N.W. (1999): Text book of clinical chemistry. ( $3^{\text {rd }}$ ed). C.A.Burtis, E.R. Ashwood, W.B. Saunders., P .477-530 to 1241-1245.

Tiwari, A.K. and J. Madhusudanarao (2002): Diabetes mellitus and multiple therapeutic approaches of phytochemicals: present status and future prospects. Curr. Sci., 83: 30-38.

Veermanic, C.; G. Pushpavalli and K.V. Pugalendi (2008): Antihyperglycemic of Cardispermum halicacabum Linn. Leaf extract on STZ induced diabetic rats. J. Appl. Biomed., 6: 19-26.

Vidro, E.; T. Basuand A. Tsin (1999): Insulin dependent diabetes mellitus and vitamin A metabolism. Special issue: Diet nutrition and health". J Clin Biochem. Nutr., 26:155-160.

Wang, Y.; Y. Zhang; B. Sun ; X. Leng ; Y. Li and L. Ren (2018): Cardioprotective effects of rutin in rats exposed to pirarubicin toxicity, Journal of Asian Natural Products Research, 20(4):361-373.

Wills, M.R. and J. Savory (1981): Biochemistry of renal failure. Ann.Clin.Lab.Sci., 11:292-299.

Yajmk, C.S. (2001): The insulin resistance epidemic in India: fetal origins, later lifestyle or both?. Nutr. Rev.,5: 1-9.

Zar, J.H. (1984): Biostatistical Analysis, second ed. Prentice-Hall, Englewood Cliffs, NJ.

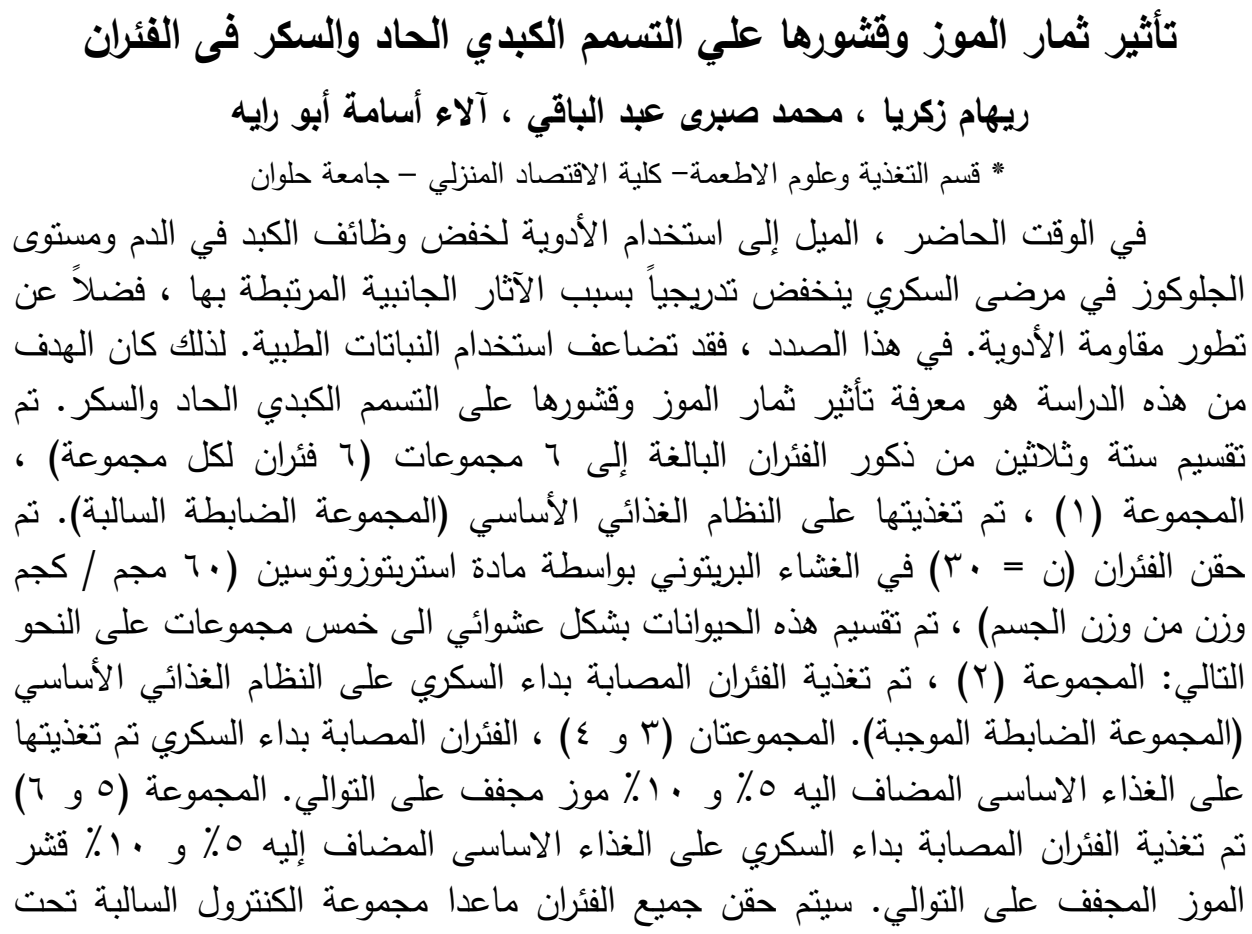


الجلد بواسطة رابع كلوريد الكربون (Ccl4) مرتين في نهاية فترة التجربة (ع أسابيع) لاحداث

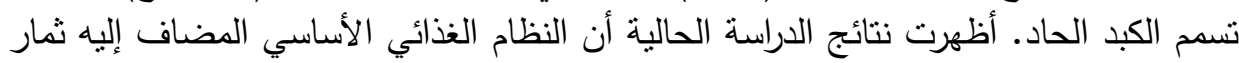

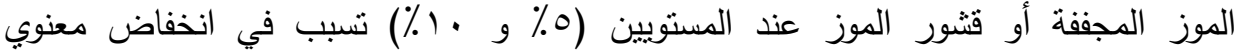

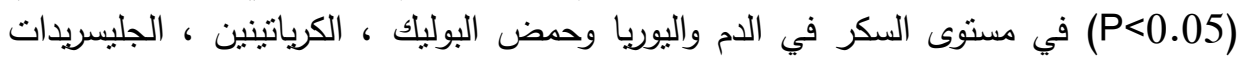

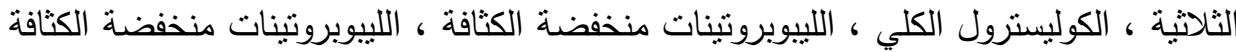

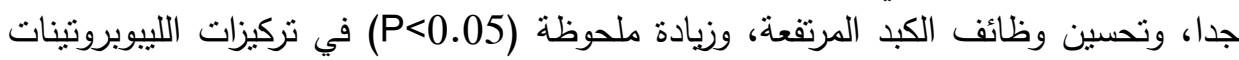

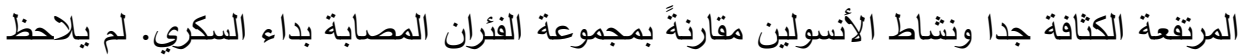
أي تغييرات إحصائية في المقاييس الكيميائية بين المجموعات التي تم معالجتها ـ ـ توضح

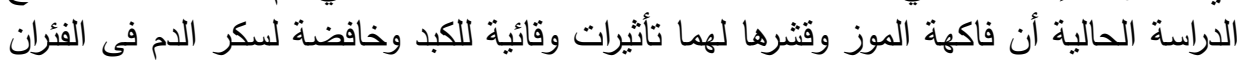
المصابة بداء السكري وارتفاع فى وظائف الكبد. 